\title{
Pemikiran Ekonomi Ibnu Khaldun dan Al-Ghazali
}

\author{
Satriana ( 90100118038 \\ ) \\ @tarhihamka@gmail. \\ com
}

Munculnya ilmu ekonomi islam dalam khasanah ilmu pengetahuan dan teknologi telah mengerahkan perhatian kepada pemikir ekonomi dari para pemikir musim dimasa lalu dan salah satu diantaranya adalah Abdurrahman Abu Zaid Waliuddin Ibnu Khaldun atau dikenal dengan nama Ibnu Khaldun. Lahir di Taunisia pada awal Ramdhan $732 \mathrm{H}$ atau bertepatan dengan 27 Mei $1332 \mathrm{M}$. sebagai pemikir ekonomi yang produktif, Ibnu Khaldun mengeluarkan banyak ide gagasan terkait dengan ilmu social termasuk didalamnya ekonomi.(Dwi, 2015)

Salah satu karya fenomenal Ibnu Khaldun adalah Kitab Al-Muqaddimah, yang selesai pemulisannya pada November 1377. Sebuah kitab yang sangat menakjubkanKarenaisinyamencakupberbagaiaspekilmudankehidupanmanusia pada saat itu. Al-Muqaddimah secara harfiah bararti 'pembukaan' atau 'introduksi' dan merupakan jilid pembuka dari tujuh jilid tulisan sejarah. Al-Muqaddimah mencoba untuk menjelaskan prinsip-prinsip yang menentukan kebangkitan dan keruntuhan dinasti yang berkuasa (daulah) dan peradaban ('umran). Tetapi bukan hanyaitusajayangdibahas.Al-Muqaddimahjugaberisidiskusiekonomi,sosiologi dan ilmu politik, yang merupakan kontribusi orisinil Ibnu Khaldun untuk cabangcabang ilmu tersebut.(Huda,2013)

Soal-soal ekonomi ini dibicarakan oleh Ibnu Khaldun di dalam bukunya "Al-Muqaddimah",bagiankeV.Motifekonomitimbulkarenahasratmanusiayang tidak terbatas, sedang barang-barang yang akan memuaskan kebutuhannya itu sangat terbatas. Sebab itu memecahkan soal-soal ekonomi haruslah dipandangdari duasudut;suduttenaga(werk, arbeid)dandarisudutpenggunaannya.Adapundari sudut tenaga terbagi kepada:

a. Tenaga untuk mengerjakan barang-barang (object) untuk memenuhi kebutuhannya sendiri (subject), dinamakan "ma'asy"(penghidupan).

b. Tenaga untuk mengerjakan barang-barang yang memenuhi kebutuhan orang banyak (Massaal subjektif), dinamakan "tamawwul”(perusahaan).

Adapun dari jurusan kegunaannya, dapatlah dibagi menjadi 2 hal:

a Kegunaan barang-barang yang dihasilkan itu hanyalah untuk kepentingannya sendiri,dinamakan“rizqy"(tersebut55kalidalamalQur"eandengan77kata-kata yangsama).

b. Kegunaannyauntukkepentinganorangbanyak,sedangkepentinganorangyang mengerjakan tidaklah menjadi tujuan utama. Hal ini dinamakan "kasab" (tersebut 67 kali dalam al-Qur'an). (Huda,2013) 
Abu Hamid Muhammad bin Muhammad bin at-Tusi al-Gazali atau lebih dikenal dengan nama Al-Ghazali, digelar Hujjah al-Islam, lahir di Ghazaleh suatu desa dekat Thus, bagian dari kota Khurasan, Iran pada tahun 450 H/1056 M AlGazali berada dalam era kehidupan ekonomi Islam era feodal militer atau perbudakan.Al-Gazalidikenalseorangteologterkemuka, ahlihukum,pemikir,ahli tasawuf dengan julukan sebagai hujjah al-Islam. al-Gazali juga belajar kepada sejumlah ulama. Kemudian menggabungkan kelompok Nizam al-Mulk, wazir sultan (Saljuk) sangat menarik para cendikiawan muda muslim. Pada tahun (484 H/1091 M) diangkat menjadi guru besar di madrasah Nizhamiyah, Bagdad selama kurang lebih 4 tahun. (Sirajuddin,2016)

Secara umum sosio ekonomi, Al-Ghazali berakar dari sebuah konsep fungsi kesejahteraan sosial Islam. Tema yang menjadi pangkal tolak seluruh karyanya adalah konsep maslahah, yakni sebuah konsep yang mencakup semua aktivitas manusiadanmembuatkaitaneratantaraindividudanmasyarakat.Al-Ghazalitelah menemukan sebuah konsep fungsi kesejahteraan sosial yang sulit diruntuhkan dan telah dirindukan oleh para ekonom kontemporer. Menurut Al-Ghazali, konsep kesejahteraan masyarakat tergantung kepada pencarian dan pemeliharaan lima tujuan dasar yakni, agama (al-din), hidup (nafs), keturunan (nasl), harta (mal), dan akal $(a q l)$. Selain itu, Al-Ghazali mendefenisikan aspek ekonomi dari fungsi kesejahteraansosialdalamkerangkasebuahhirarkiutilitasindividudansosialyang tripartite,yaknikebutuhan(daruri),kesenangan(hajat),dankemewahan(tahsinaat) AlGhazali memandang bahwa perkembangan ekonomi sebagai bagian dari tugastugaskewajibansosialyangsudahditetapkanAllah.Jikatidakdipenuhikehidupan duniaakanruntuhdankemanusiaanakanbinasa,aktivitasekonomiharusdilakukan secara efisien karena merupakan bagian dari pemenuhan tugas keagamaan seseorang.Adatigaalasanmengapaseseorangharusmelakukanaktivitasekonomi;

a. Untuk mencukupi kebutuhan hidup yangbersangkutan.

b. Untuk mensejahterakankeluarga.

c. Untuk membantu orang lain yang membutuhkan. Menurutnya tidak terpenuhinya ketiga alasan ini dapat dipersalahkan oleh agama. (Faizal,2015)

Kunci pemeliharaan dari kelima tujuan dasar ini terletak pada tercukupinya kebutuhan atau utilitas individu dan sosial. Al-Ghazali membagi utilitas ini dalam tiga hierarki yang disebut tripartite. Pertama, kebutuhan (daruriyat) meliputi makanan,pakaian,danperumahan.Kedua,kesenanganataukenyamanan (hajiyat). Kelompok kedua ini terdiri dari semua kegiatan yang tidak vital bagi lima fondasi tersebut, tetapi dibutuhkan untuk menghilangkan rintangan dan kesukaran dalam hidup. Ketiga, kemewahan (tahsiniyat). Kelompok ketiga ini mencakup kegiatankegiatan yang lebih jauh dari sekedar kenyamanan saja, namun mencakup hal-hal yang bisa melengkapi, menerangi atau menghiasi hidup.(Rahmawati,2012) 


\section{DAFTAR PUSTAKA}

Dwi, Martina. 2015. Menelaah Pemikiran Ekonomi Ibnu Khaldun. Kholdunomic Vol.9 No.1. hal. 81-102.

Faizal, M. (2015). Studi Pemikiran Imam Al-Ghazali Tentang Ekonomi Islam. Islamic Banking, Vol.1 No.1. hal. 49-58.

https://media.neliti.com/media/publications/287369-studi-pemikiran-imamal-ghazali-tentang-bd516d22.pdf

Huda, C. (2013). Pemikiran Ekonomi Bapak Ekonomi Islam; Ibnu Khaldun. Economica: Jurnal Ekonomi Islam, Vol.4 No.1. hal. 103-124. https://doi.org/10.21580/economica.2013.4.1.774

Rahmawati, L. (2012). KONSEP EKONOMI AL-GHAZALI Lilik Rahmawati (Dosen Fakultas Syariah IAIN Sunan Ampel). Jurnal Ekonomi Syariah, Vol. 02 No.01. hal. 329-345.

Sirajuddin. 2016. Konsep Pemikiran Ekonomi Al-Gazhali. LA MAIYSIR, Vol.3 No.1. hal. 46-60. 